\title{
Po stopách Slovanov
}

\author{
Paolo Di Vico (Nitra)
}

Marcello Garzaniti: Gli slavi. Storia, culture e lingue dalle origini ai nostri giorni. Roma: Carocci, 2013. 473 pp. ISBN 978-88-430-6807-4.

\begin{abstract}
Poznanie slovanského sveta a prúdov, ktoré v ňom prebiehajú a ktoré ho formujú, zodpovedá poznaniu velkej časti európskej kultúry, a to už od 9.-10. storočia, kedy sa v dejinách objavili Slovania a na vytýčenie vlastnej historickej cesty až k súčasnosti si vybrali latinsko-germánsku
\end{abstract} a byzantskú oblast', charakterizovanú významným vplyvom a vývojom. Homogénnost' slovanskej skutočnosti sa tak začala postupne rozplývat', vznikali diferencované reality, podstatné pre hlbšie pochopenie dejín Európy, avšak napriek tomu často opomínané kvôli oneskorenému šíreniu myšlienky štátnosti v týchto končinách. Ak však skúmame presadenie sa slovanských kultúr v rozšírenej historickej perspektíve, stávame sa svedkami vyprofilovania sa dejín štátov, často postavených proti sebe a napriek tomu nevzdávajúcich sa myšlienky spoločnej slovanskej civilizácie, ktorá práve vd’aka tomu, že je braná do úvahy ako celok, umožňuje pozorovat' jej rôznorodé zložky univerzálnejším spôsobom, orientovaným hlavne na obsadenie vlastného pevného miesta v európskom kontexte.

Dejiny slovanských národov stále balansujú medzi dvoma protikladnými pólmi, pričom nikdy úplne nevstupujú do žiadneho z nich, teda ani do obzoru vymedzeného štátnymi hranicami a ani do opačného pólu vedeného panslavistickou ideológiou, ktorá hlavne z politických dôvodov poznačila rôzne skoršie historické obdobia. Nemožno zabudnút' ani na prínos iných národov a kultúr do slovanskej evolúcie, ale bez toho, aby sme podstúpili riziko považovat' dejiny európskej civilizácie pre jej aspekty kultúrneho a sociálneho pokroku za výhradnú výsadu Západu, ktorému sa menšinové kultúry, hoci v slovanskom prípade takými neboli, postupne prispôsobovali. Z uvedeného vyplýva takmer okrajová pozornost' venovaná
Východnej Európe, ako územiu zažívania toho, čo už bolo vyskúšané a pochádzalo zo Západu, ktorá viedla $\mathrm{k}$ interpretačným rozporom a zároveň odhalila potrebu väčšieho a lepšieho chápania histórie takzvaných marginálnych území, tak ako aj ich tendencie k europeizácii a k zachovaniu vlastných pôvodných charakteristík, europeizácii poňatej ako vôli nadviazat'na spoločné inklinácie, ktorá nemá byt’pochopená ako len čisté napodobňovanie a prispôsobovanie sa modelom dovezeným odinakial.

Predložená práca slavistu Marcella Garzanitiho si kladie za ciel' definovat' základné smery kultúrno-historickej slovanskej evolúcie, pričom obracia pozornost' na osudy jednotlivých národov a zároveň na spoločne zdielaný základ, inšpirovaný dvoma hlavnými smermi, ktorými sa slovanské kultúry vybrali. Ide samozrejme o hodnotenie na základe ich inklinácii k latinskému Západu alebo k byzantskému Východu, pričom sa uznáva príslušné a už tradične zaužívané pomenovanie latinská Slavia ortodoxná Slavia, identifikujúce dve odlišné dynamické evolúcie, ktoré však nedokážu zachytit'slovanský svet $\mathrm{v}$ jeho plnom bohatstve a rozmanitosti. Za týmto účelom autor radšej sledoval nielen lingvistické a literárne cesty, ale v celkovom zobrazení reálnu civilizáciu aj s cielom nájst'kultúrne tendencie, ktoré by umožnili pochopit' spôsoby správania sa a situácie, ktoré pretrvávajú až do dnešnej doby. Celkový príbeh Slovanov je členený podla presného historického kritéria, vychádza zo spoločného pôvodu a striktnou chronologickou progresiou určuje procesy, ktoré nasledovali jeden za druhým a boli prínosom pre posilnenie slovanskej reality, ktorá na historickej scéne už bola roztrieštená. Samozrejme, boli zvolené prístupové klúče vhodné pre interpretáciu tejto rozsiahlej výskumnej sféry, ktoré boli identifikované v kultúrnych a nábo- 
ženských prúdoch a v lingvistických otázkach, analyzovaných aj v ich nevyhnutnom prepletení sa na pozadí filozofických, spoločenských a teologických prvkov. Uvedené tendencie premietnuté na obzvlášt' dlhý a komplexný časový oblúk sú naznačené najmä so zámerom určit' ich význam $\mathrm{v}$ širokom európskom kontexte, pričom sa autor sústreduje na podstatné otázky, ktoré sú skúmané používaním výsledkov pochádzajúcich z multidisciplinárneho prístupu.
Vdaka svojej koncepcii tvorí Garzanitiho kniha kultúrnu syntézu venovanú multidisciplinárnym cielom a umožňuje prístup k informáciám špecialistom z rôznych vedeckých domén (lingvistom, literátom, historikom), ako aj neodbornému zvedavému čitatelovi cítiacemu potrebu spoznat' sugestívny a fascinujúci svet, bohatý na podnety a myšlienky, svet ktorý sa nám odhaluje nie ako vzdialená a oddelená skutočnost', ale ako súčast' európskej kultúrnej panorámy.

\section{Mgr. Paolo Di Vico}

Katedra romanistiky

Filozofická fakulta, Univerzita Konštantína Filozofa v Nitre Hodžova 1, 94974 Nitra, Slovensko

pdvico@ukf.sk 